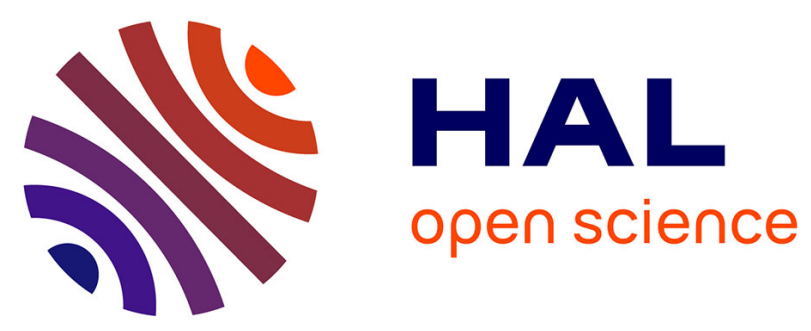

\title{
Schizophrenia: validity of a 3-hit mouse model
}

Solenn Percelay, Thomas Freret, Boubacar Diarra, Nicolas Delcroix, Elise

Leroux, Annie Andrieux, Sonia Dollfus, Michel Boulouard, Valentine Bouët

\section{To cite this version:}

Solenn Percelay, Thomas Freret, Boubacar Diarra, Nicolas Delcroix, Elise Leroux, et al.. Schizophrenia: validity of a 3-hit mouse model. 11th Federation of European Neuroscience Societies Forum of Neuroscience, Jul 2018, Berlin, Germany. , 2018. hal-02135529

HAL Id: hal-02135529

https://hal-normandie-univ.archives-ouvertes.fr/hal-02135529

Submitted on 21 May 2019

HAL is a multi-disciplinary open access archive for the deposit and dissemination of scientific research documents, whether they are published or not. The documents may come from teaching and research institutions in France or abroad, or from public or private research centers.
L'archive ouverte pluridisciplinaire HAL, est destinée au dépôt et à la diffusion de documents scientifiques de niveau recherche, publiés ou non, émanant des établissements d'enseignement et de recherche français ou étrangers, des laboratoires publics ou privés. 
